\title{
PROTOTIPE LORI INSPEKSI ELEKTRIK BERTENAGA SURYA (LORI PPI E-2000 GENERASI 3)
}

\author{
Dadang Sanjaya Atmaja ${ }^{1}$, Email: dadang@ppi.ac.id \\ Henry Widya Prasetya ${ }^{2}$, Email : henry@ppi.ac.id \\ 1,2 Teknologi Mekanika Perkeretaapian, Politeknik Perkeretaapian Indonesia Madiun
}

\begin{abstract}
ABSTRAK
Penggunaan lori inspeksi dalam kegiatan perawatan prasarana sangat dibutuhkan untuk meminimalisir tenaga dalam pemeliharaan dan efisiensi waktu. Pengembangan lori inspeksi di Politeknik Perkeretaapian Indonesia Madiun terus dilakukan mulai dari motor penggerak, roda, frame, bodi, rubber dumper dan panel surya sebagai sumber energi utama. Motor penggerak menggunakan motor listrik BLDC (Brushless direct current) dengan daya $2680 \mathrm{Watt}$, arus $35 \mathrm{~A}$ dan kecepatan putar $4250 \mathrm{Rpm}$ yang ramah lingkungan. Pengembangan roda lori inspeksi menggunakan struktur monoblok dengan proses pengecoran. Material yang digunakan berasal dari besi cor nodular (FCD), memiliki tingkat kekerasan rata-rata $191 \mathrm{HB}$. Rubber damper dikenal sebagai peredam kejut dengan panjang $185 \mathrm{~mm}$, lebar $60 \mathrm{~mm}$, dan tinggi $30 \mathrm{~mm}$. Komposisi bahan Rubber damper sebagai berikut: Karet alam 55\%, Carbon black 25\%, White oil 5\%, Zine oxide 3\%, Accelerator 2\%, Anti Oxidant 2\%, Steread Axid 3\%, dan Sulfur 5\%. Bodi lori inspeksi terbuat dari material komposit jenis fibre reinforced polymers of plastics (FRP). Komposit ini menggunakan polimer berbahan resin polyester sebagai matriks (pengikat) dan penguatan serat gelas jenis fibrous dengan metode hand lay-up. Solar panel sebagai sumber energi utama untuk mensuplai daya arus listrik motor listrik penggerak. Solar panel dapat bekerja dengan optimal dengan presentasi Pmax mencapai 99,29\% dan kemampuan jarak tempuh sejauh $11 \mathrm{Km}$. Alat pengukur geometri jalan rel dilengkapi dengan sensor maxbotik sebagai pendeteksi lebar jalan rel, gyroscope sebagai pendeteksi beda tinggi dan KTR displacement sensor sebagai pendeteksi keausan rel. Desain lori inspeksi elektrik PPI Madiun memiliki nilai estetika maupun ergonomi yang tinggi.
\end{abstract}

Kata Kunci: Lori inspeksi elektrik, roda, chassis, bodi komposit, rubber dumper, panel surya, alat ukur geometri rel

\section{ABSTRACT}

The use of inspection lorries in infrastructure maintenance activities is needed to minimize labor in maintenance and time efficiency. The development of inspection lorries at the Indonesian Railroad Polytechnic of Madiun continues, starting from the motor, wheels, frames, body, rubber dumper and solar panels as the main energy source. The motor uses a BLDC (Brushless direct current) electric motor with a power of 2680 Watts, a current of $35 \mathrm{~A}$ and a rotating speed of 4250 Rpm which is environmentally friendly. The development of the inspection lorry uses a monoblock structure with a casting process. The material used comes from nodular cast iron (FCD), having an average hardness of 191 HB. Rubber dampers are known as shock absorbers with a length of 185 $\mathrm{mm}$, a width of $60 \mathrm{~mm}$, and a height of $30 \mathrm{~mm}$. The composition of the Rubber damper material is as follows: 55\% natural rubber, 25\% Carbon black, 5\% White oil, 3\% Zine oxide, 2\% Accelerator, $2 \%$ Anti Oxidant, 3\% Steread Axid, and 5\% sulfur. The inspection lorry body is made of fiber reinforced polymers of plastics (FRP) type composite material. This composite uses a polymer made from polyester resin as a matrix (binder) and strengthens fibrous glass fibers using the hand lay-up method. Solar panels are the main energy source to supply the electric motor power. Solar panels can work optimally with a Pmax presentation reaching $99.29 \%$ and a range of $11 \mathrm{~km}$. The railroad geometry measuring device is equipped with a maxbotic sensor to detect rail road width, a gyroscope 
as a height difference detector and a KTR displacement sensor to detect rail wear. The design of the PPI Madiun electric inspection lorry has high aesthetic and ergonomic value.

Keyword: Electrical inspection lorries, wheels, chassis, composite body, rubber dumper, solar panels, rail geometry gauges.

\section{PENDAHULUAN}

Dalam proses perawatan prasarana perkeretaapian, dibutuhkan alat transportasi yang mampu mempercepat proses perawatan, efisiensi waktu, dan proses yang mudah dalam pengoperasian. Lori inspeksi yang handal merupakan solusi yang dibutuhkan guna untuk melakukan kegiatan proses perawatan prasarana perkeretaapian. Lori inspeksi adalah kendaraan angkut dengan atau tanpa penggerak sendiri yang dapat diangkat dari rel di jalan bebas oleh tenaga yang ada pada kendaraan tersebut dalam waktu tidak lebih dari 2 menit, dan digunakan untuk memeriksa prasarana serta membawa petugas dan/atau material kerja. Lori inspeksi terdiri dari struktur-struktur penyusun seperti roda, chassis, body, suspensi, dan motor untuk penggerak.

Dalam perancangan dan pembuatan prototype lori inspeksi elektrik Politeknik Perkeretaapian Indonesia Madiun ini dengan penggerak menggunakan motor listrik brushless DC (BLDC). Dengan berbagai metode pengontrol kecepatan dan upaya peningkatan performa motor listrik.

Roda kereta merupakan jenis roda yang dirancang khusus untuk digunakan pada rel kereta api. Roda kereta merupakan bagian dari bogie dan terbuat dari baja karbon yang ditempa (forging), dipasang pada gandar (axle) dilengkapi saluran pelumas yang dilengkapi penutup karet heksagonal (seal head plug hexagonal).

Bodi merupakan bentuk maupun tempat pada sebuah/kendaraan yang biasanya digunakan sebagai pembentuk kendaraan dan tempat untuk pelindung bagi penumpang dari paparan hujan dan sinar matahari. pada umumnya bodi ini terbuat dari bahan plat logam (steel plate) yang memiliki tebal antara 0,6 $\mathrm{mm}$ hingga 0,9 mm dan juga bahan komposit (Composite) yang terbuat dari material yang tersusun atas campuran dua atau lebih material dengan sifat kimia dan fisik berbeda. Dalam bodi sendiri pada bagian dalamnya terdapat suatu kerangka yang berfungsi sebagai penguat kendaraan tersebut serta membuat kerangka dari suatu kendaraan menjadi lebih nyaman. Selain sebagai aspek kenyamanan dan juga keamaan untuk para penumpang, bodi kendaraan ini juga memiliki nilai seni yang tinggi. Chassis lori inspeksi menggunakan ledder frame untuk mendapatkan hasil yang optimal pada track 1067.

Sistem suspensi adalah suatu mekanisme yang dipasang antara rangka, body dan roda yang berfungsi untuk menahan dan meredam kejutan selain bermanfaat bagi umur kendaraan, suspensi juga sangat bermanfaat bagi pengemudi dan penumpang. Mereka lebih nyaman dalam mengemudikan kendaraan. Rubber damper atau peredam kejut pada lori inspeksi ini dibuat dengan komposisi bahan karet alam.

Energi Surya merupakan sumber energi yang terbarukan dan tidak akan pernah habis ketersediaannya dan energi ini juga dapat dimanfaatkan sebagai energi alternatif yang akan diubah menjadi energi listrik, dengan menggunakan sel surya pengisian battery lithium dapat dilaksanakan pada kondisi saat terdapat matahari. Pemasangan battery lithium dan solar panel merupakan tenaga baru pada Lori Elektrik PPI Madiun,

Pada dasarnya pemeriksaan jalan rel meliputi pemeriksaan geometri, komponen, badan jalan, drainase, konstruksi jembatan dan terowongan. Pemeriksaan wajib pada geometri jalan rel diantaranya lebar jalan 
rel, kelandaian, lengkung, peninggian dan pelebaran jalan rel. Pelebaran dan peninggian rel mempengaruhi kemiringan sarana yang mengakibatkan flens roda bergesekan dengan permukaan kepala rel. Gesekan antara flens roda dan permukaan kepala rel mengakibatkan rel semakin aus. Maka dari itu pemeriksaan keausan rel juga dilakukan secara berkala agar tidak melebihi toleransi yang berlaku. Diperlukan alat bantu ukur geometri rel pada lori inspeksi PPI Madiun untuk meningkatkan mobilitas Petugas Pemeriksa Jalur dalam melakukan pemeriksaan jalan rel. Alat bantu ini diharapkan dapat membantu memeriksa jalan rel dengan waktu yang singkat dan mendapatkan data yang akurat.

\section{METODE PENELITIAN}

Metode penelitian yang digunakan adalah metode penelitian eksperimental. Metode penelitian ini yaitu melakukan pengamatan untuk mencari data kuantitatif dalam suatu proses melalui penelitian sehingga dapat mengetahui sebab-akibat. Alur pikir penelitian pembuatan prototype lori inspeksi elektrik Politeknik Perkeretaapian Indonesia Madiun sebagai berikut :

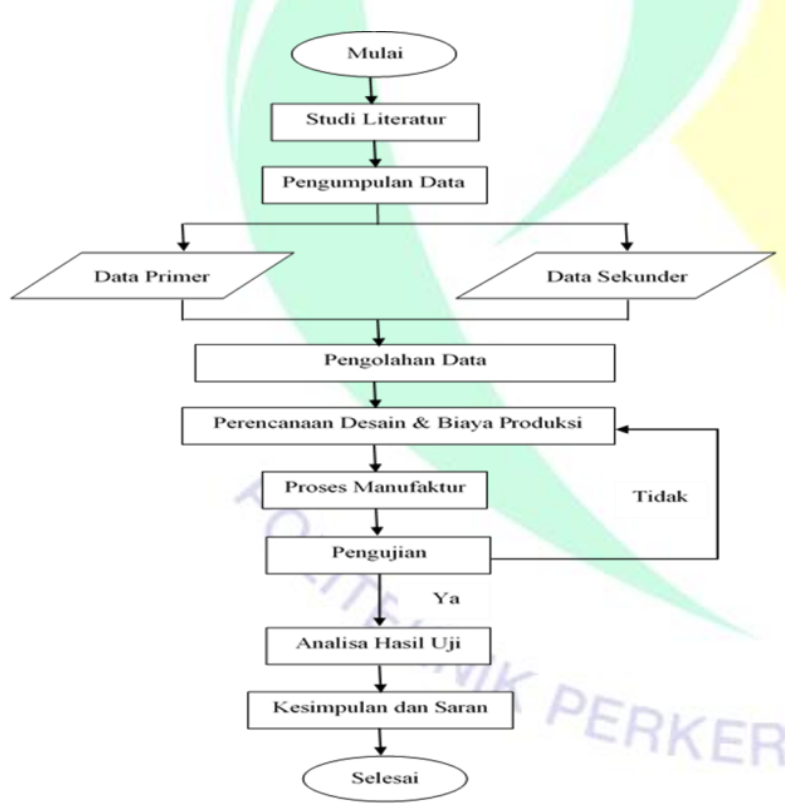

Gambar 1. Metode Penelitian

\section{HASIL DAN PEMBAHASAN}

\section{Chassis Lori Inspeksi Elektrik}

Kerangka dibuat dengan mempertimbangkan kekuatan untuk menompang solar panel yang akan dipasang sebagai suplai energi lori inspeksi. Bagian pipa baja karbon rendah dirakit sesuai desain dan disambungkan dengan metode pengelasan. Berikut desain dari lori inspeksi elektrik Politeknik Perkeretaapian Indonesia Madiun :

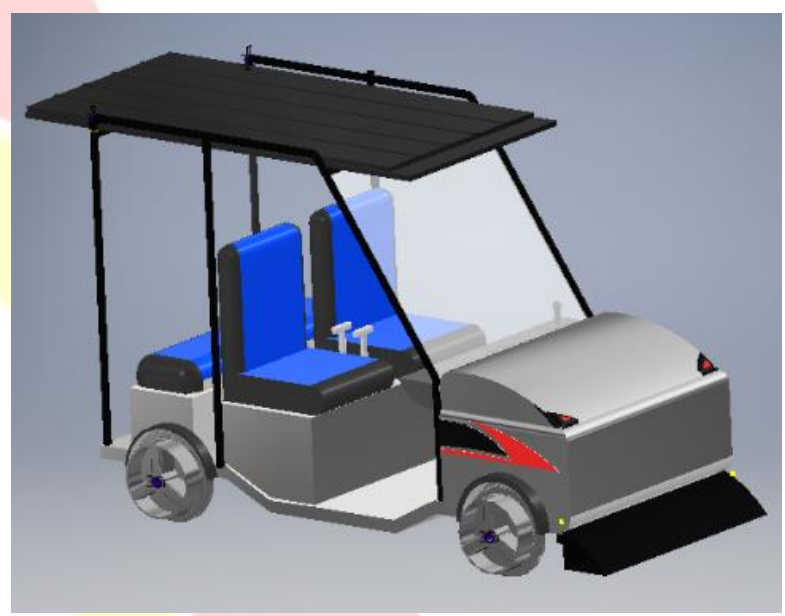

Gambar 2. Desain lori inspeksi

Pengujian beban dilakukan dengan menggunakan aplikasi yang dapat menguji tingkat kekuatan pada saat pembebanan yaitu dengan cara menggunakan software SolidWorks 2017. Pada proses pengujian pembebanan ini dilakukan dengan beberapa beban yang diberikan yaitu dengan beban $200 \mathrm{~N}$ dan $500 \mathrm{~N}$.

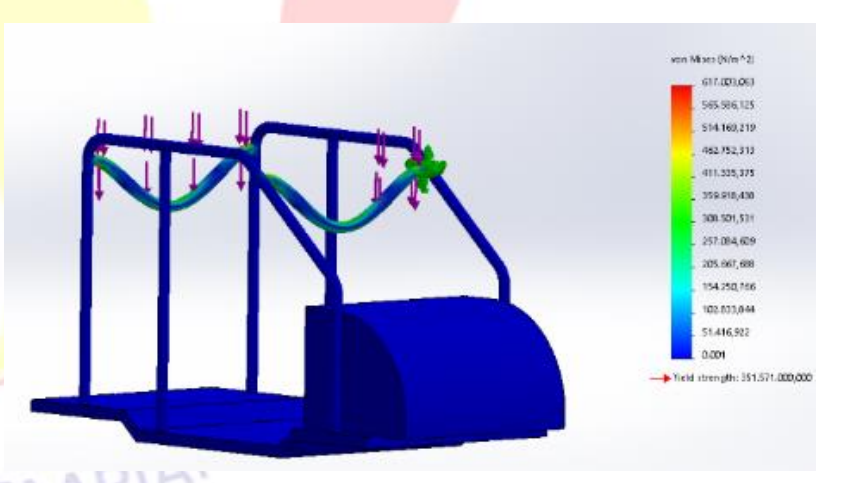

Gambar 3. Pengujian Beban $200 \mathrm{~N}$

Pada pengujian yang dilakukan dengan menggunakan berat $200 \mathrm{~N}$, hasil pengujian menyatakan bahwa bahan yang 
digunakan dalam pembuatan kerangka termasuk aman dikarenakan tegangan yang diterima bahan masih dibawah tegangan ijin bahan. Defleksi yang terjadi akibat pembebanan gaya luar masih mampu ditahan oleh material chassis lori inspeksi.

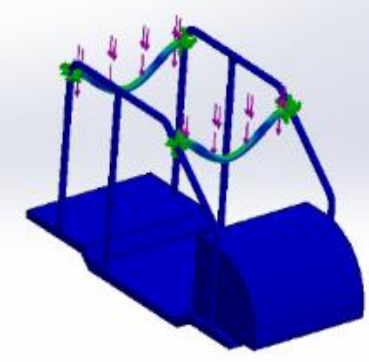

Gambar 4. Pengujian Beban 500 N

Pada pengujian kedua, dilakukan dengan menggunakan beban berat sebesar $500 \mathrm{~N}$ pada tumpuan kerangka lori. Pada percobaan yang dilakukan, tampak kerangka mengalami tekanan tetapi tidak sampai merusak struktur dari kerangka. Sehingga pada percobaan ini dinyatakan cukup aman dalam pengoperasian dengan beban $500 \mathrm{~N}$.

\section{Bodi Lori Inspeksi Elektrik}

Bodi merupakan bentuk maupun tempat pada sebuah kendaraan yang biasanya digunakan sebagai pembentuk kendaraan dan tempat untuk pelindung bagi penumpang dari paparan hujan dan sinar matahari. Pembuatan bodi lori inspeksi menggunakan bahan komposit polymer berbahan resin polyester sebagai matriks (pengikat) dengan penguatan serat gelas jenis fibrous, atau biasa disebut fiberglass. Pembuatan komposit menggunakan metode hand lay-up.

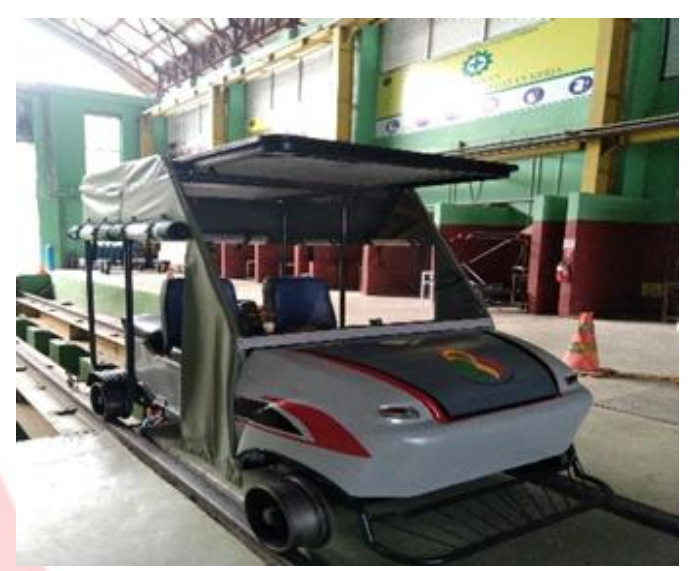

Gambar 5. Bodi lori inspeksi

Berikut pada gambar dibawah ini dijelaskan hasil pengujian kekuatan Tarik dari material komposit yang digunakan sebagai bodi lori inspeksi.

GRAFIK UJI TARIK SAMPEL B

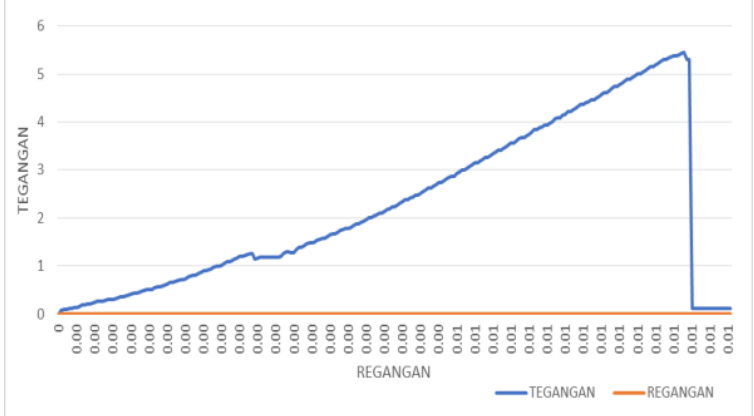

Gambar 6. Grafik tegangan dan regangan spesimen bodi komposit lori inspeksi

\section{Roda Lori Struktur Monoblok}

Desain roda lori inspeksi elektrik PPI Madiun mempertimbangkan track/jalur yang akan dilewati. Hal ini bertujuan agar saat dilakukan uji coba tidak akan mengalami anjlok ataupun terselip. Sehingga bentuk profil roda berpengaruh pada kelancaran jalannya roda bergerak diatas rel. 


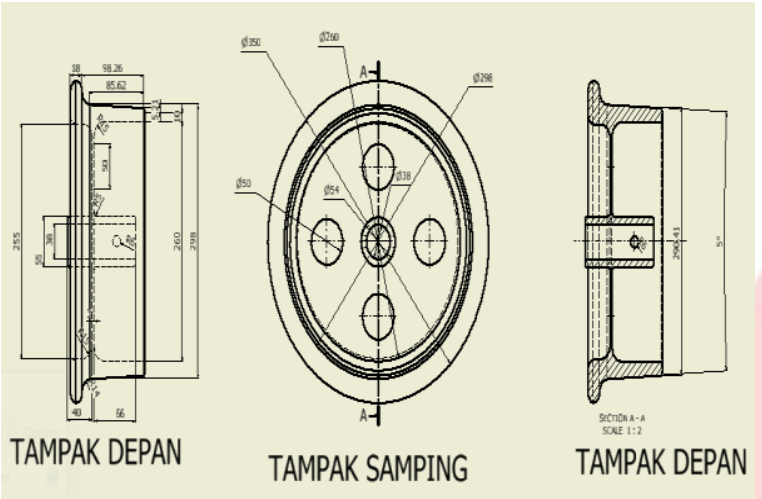

Gambar 7. Desain Roda Lori Inspeksi

Pada saat roda berjalan di track roda akan mengalami gerak ke kiri dan ke kanan secara tidak stabil yang dinamakan gerakan snake motion. Maka dari itu roda yang telah dirancang seperti ukuran diatas harus bisa berjalan dengan baik, seperti berjalan di lengkungan roda tidak bergesekan dengan rel gongsol, berjalan di perlintasan sebidang roda tidak anjlok, dan tapak roda bisa menompang dengan baik.

Dengan ukuran desain roda yang telah ditentukan di atas, maka saat melewati lengkungan tapak roda harus tetap dapat menopang dengan baik tanpa terjadinya anjlok dan flens roda tidak bergesekan dengan rel paksa, dengan perhitingan:

Panjang poros + lebar flens + lebar tapak roda $<$ lebar lengkung terpanjang + lebar rel

$1019 \mathrm{~mm}+20 \mathrm{~mm}+84 \mathrm{~mm}<1090 \mathrm{~mm}+$ $70 \mathrm{~mm}$

\section{$1123 \mathrm{~mm}<1160 \mathrm{~mm}$}

Sehingga dengan hasil diatas dipastikan tapak roda masih menopang dengan baik saat melewati lengkungan.

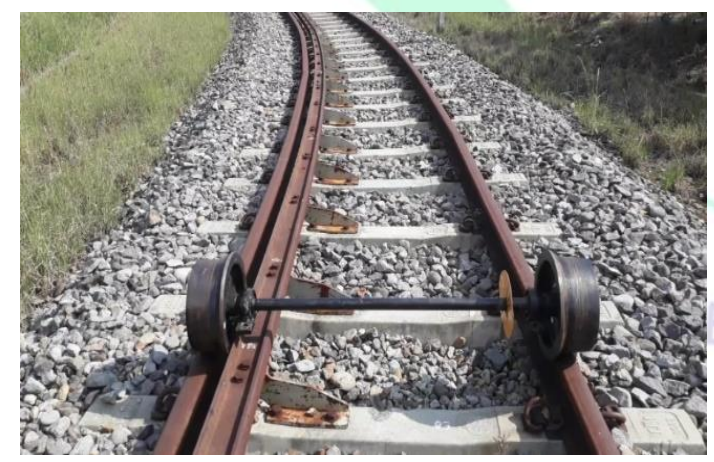

Gambar 1.8 Roda Berjalan Pada lengkungan
Untuk memastikan roda mampu melewati wesel dengan lancar maka dengan memastikan bahwa lebar antar keeping roda + flens < lebar wesel

\section{$1019 \mathrm{~mm}+40 \mathrm{~mm}<1065 \mathrm{~mm}$}

Sehingga dapat dipastikan roda bisa melewati wesel.

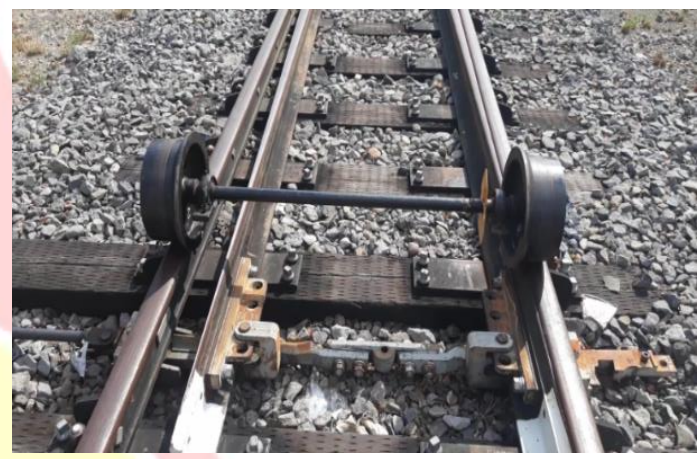

Gambar 9. Roda Melewati wesel

Pengujian keretakan dilakukan untuk mengetahui cacat pada permukaan tapak roda setelah dilakukan proses pembubutan, adanya keretakan atau tidak. Pengujian ini merupakan Non Destructive Test dan dilakukan dengan metode Liquid Penetrant Test.

Pegujian keretakan pada permukaan tapak roda yang mengalami proses pembubutan menghasilkan tidak adanya bercak merah pada tapak roda setelah disemprotkan developer penetran. Dimana roda dari proses pengecoran memiliki kepadatan yang tinggi, sehingga menandakan roda dari proses pengecoram besi memiliki kekuatan terhadap benturan dan kuat meskipun setelah melewati proses pembubutan. Seperti dilihat pada gambar di atas.

Tabel 1. Hasil Tingkat Kebisingan Roda Lori Monoblok

\begin{tabular}{|l|l|l|l|l|l|}
\hline $\begin{array}{l}\text { Kecepatan } \\
(\mathrm{km} / \mathrm{jam})\end{array}$ & \multicolumn{3}{|l|}{ Tingkat Kebisingan (dBA) } & $\begin{array}{l}\text { Rata-Rata } \\
(\mathrm{dBA})\end{array}$ & Rata-Rata \\
\hline 5 & 82,7 & 80,1 & 80,5 & 81,1 & $62,4 \%$ \\
\hline 10 & 86,7 & 87,1 & 86,1 & 86,6 & $66,6 \%$ \\
\hline 15 & 92,7 & 90,9 & 92,0 & 91,8 & $70,6 \%$ \\
\hline
\end{tabular}

Pengujian kekerasan dilakukan pada bagian tapak roda dan flens. Sepanjang 
lebar tapak roda di berikan 4 titik untuk diambil nilai pengujiaanya. Hal ini dilakukan karena pengujian pada benda berbentuk lingkaran harus dibentangkan seperti persegi empat sehingga diambil 4 titik bagian.

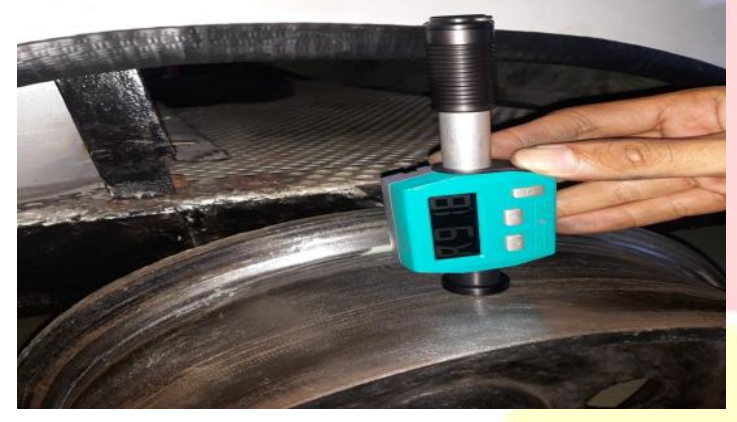

Gambar 10. Pengujian Kekerasan Roda Monoblok

Setelah dilakukan pengujian terhadap roda lori monoblok dengan metode Rockwell (HRb) didapatkan data sebagai berikut:

Tabel 2. Tingkat Nilai Kekerasan Roda Monoblok

\begin{tabular}{|c|c|c|c|c|c|}
\hline \multirow{2}{*}{ Roda } & \multicolumn{4}{|c|}{ Nilai di Titik Pengujian (HRb) } & \multirow{2}{*}{$\begin{array}{l}\text { Rata-Rata } \\
(\mathrm{HRb})\end{array}$} \\
\hline & Titik a & Titik b & Titik c & Titik d & \\
\hline 1 & 95,7 & 91,8 & 93,3 & 90,2 & 92,7 \\
\hline 2 & 90,7 & 93,7 & 98,5 & 88,7 & 92,9 \\
\hline 3 & 91,8 & 92,0 & 95,0 & 90,0 & 92,2 \\
\hline 4 & 93,3 & 90,4 & 93,5 & 88,8 & 91,5 \\
\hline
\end{tabular}

\section{Peredam Kejut (Rubber Damper)}

Karet peredam pada lori inspeksi merupakan suatu komponen yang berfungsi untuk meredam getaran dan menahan beban yang diberikan oleh lori, baik beban maksimal dan beban lori dalam keadaan normal. Kemudian untuk kelebihan dari karet ini adalah dapat menahan beban hinga 30 Psi. Berikut adalah gambar desain rubber dumper lori inspeksi :
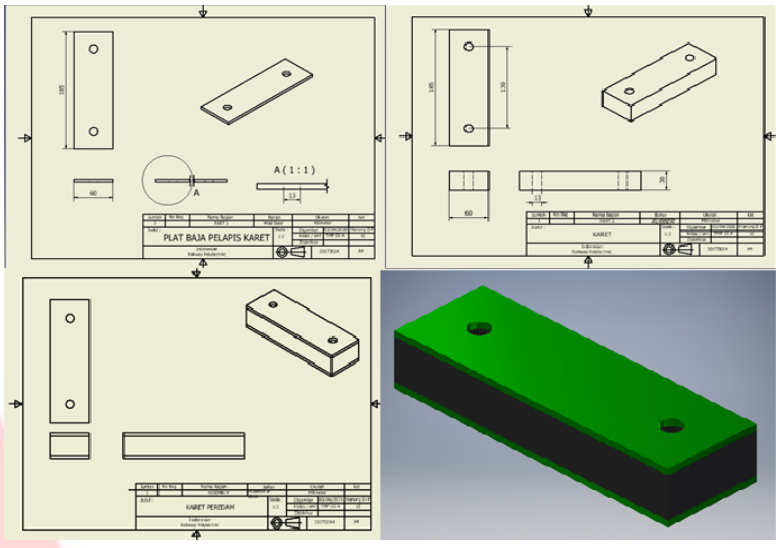

Gambar 11. Desain karet

Berikut komposisi bahan produksi rubber dumper lori inspeksi sebagai berikut:

Tabel 3. Komposisi bahan

\begin{tabular}{|l|l|l|}
\hline No & Nama bahan & kadar \\
\hline 1 & Karet alam & $55 \%$ \\
\hline 2 & Carbon black & $25 \%$ \\
\hline 3 & White oil & $5 \%$ \\
\hline 4 & Zine oxide & $3 \%$ \\
\hline 5 & Accelerator & $2 \%$ \\
\hline 6 & Anti Oxidant & $2 \%$ \\
\hline 7 & Steread Axid & $3 \%$ \\
\hline 8 & Sulfur & $5 \%$ \\
\hline
\end{tabular}

Komposisi karet menggunakan campuran karet alam dengan penambahan carbon black dan menggunakan sistem pemvulkanisasi dengan campuran sulfur. Penggunaan karet alam yang dominan dikarenakan karet alam memiliki sifat mekanis daya elastisitas dan daya lentur yang baik, plastis, dan tidak mudah panas dan tidak mudah retak.

\section{Pengujian Damper}

Uji beban atau tekanan dilakukan untuk mengetahui kekuatan rubber dumper dalam menerima gaya atau tekanan dari luar. Berikut grafik uji tekanan terhadap rubber dumper : 


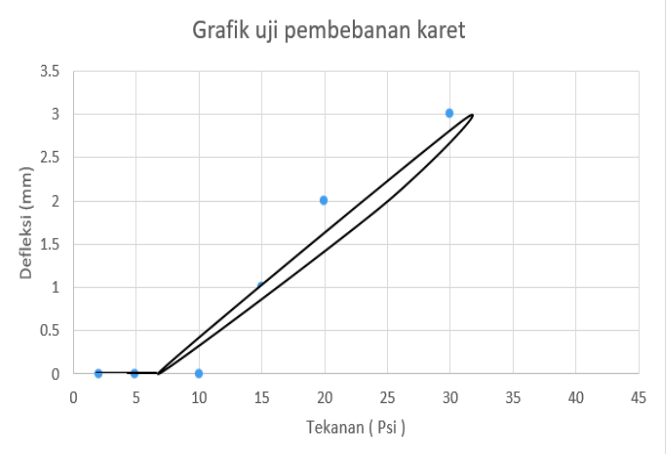

Gambar 12. Grafik uji pembebanan

Berdasarkan grafik maka dapat dilihat bahwa semakin tinggi tekanan yang diberikan kepada karet damper, maka akan semakin besar pula defleksi yang akan diterima damper. Dan damper akan kembali ke bentuk semula apabila tekanan yang diberikan terus berkurang sampai dengan angka 0 psi.

\section{Solar panel Lori Inspeksi Elektrik}

Spesifikasi yang terdapat pada solar panel lori PPI Madiun menunjukkan Pmax (daya keluaran maksimal) sebesar $330 \mathrm{~W}$. Cara menentukan Pmax adalah hasil perkalian dari Tegangan Operasi Optimal (Vmp) dengan Arus Operasi Optimal (Imp) Pada penelitian ini peneliti melakukan pengukuran tegangan dan arus yang masuk dari solar panel menggunakan alat avometer, Hasil dari perkalian tegangan dan arus menjadi acuan untuk membuktikan daya dari solar panel lori PPI Madiun. Pengambilan data dilaksanakan dari jam 7:00 sampai jam 16:00 setiap 1 jam sekali. Data dapat dilihat pada tabel berikut

Tabel 4. Data pengukuran pmax

\begin{tabular}{|l|l|l|l|}
\hline No & jam & Pmax \\
\cline { 3 - 4 } & & Hari 1 & Hari 2 \\
\hline 1 & $7: 00$ & $326,43 \mathrm{~W}$ & $325,62 \mathrm{~W}$ \\
\hline 2 & $8: 00$ & $327,06 \mathrm{~W}$ & $326,27 \mathrm{~W}$ \\
\hline 3 & $9: 00$ & $327,2 \mathrm{~W}$ & $327,06 \mathrm{~W}$ \\
\hline 4 & $10: 00$ & $327,85 \mathrm{~W}$ & $327,2 \mathrm{~W}$ \\
\hline 5 & $11: 00$ & $328,64 \mathrm{~W}$ & $328,64 \mathrm{~W}$ \\
\hline 6 & $12: 00$ & $329,94 \mathrm{~W}$ & $329,16 \mathrm{~W}$ \\
\hline 7 & $13: 00$ & $329,16 \mathrm{~W}$ & $328,64 \mathrm{~W}$ \\
\hline 8 & $14: 00$ & $328,64 \mathrm{~W}$ & $327,85 \mathrm{~W}$ \\
\hline 9 & $15: 00$ & $327,06 \mathrm{~W}$ & $325,62 \mathrm{~W}$ \\
\hline 10 & $16: 00$ & $324,81 \mathrm{~W}$ & $325,20 \mathrm{~W}$ \\
\hline
\end{tabular}

\begin{tabular}{|l|l|l|l|}
\hline & jumlah & $3276,79 \mathrm{~W}$ & $3271,26 \mathrm{~W}$ \\
\hline & Rata-rata & $327,679 \mathrm{~W}$ & $327,126 \mathrm{~W}$ \\
\hline
\end{tabular}

Pada tabel diatas menunjukkan hasil perkalian antara tegangan dan arus solar panel berupa daya pada hari pertama dan hari kedua. Berikut adalah grafik dari tabel Pmax hari pertama :

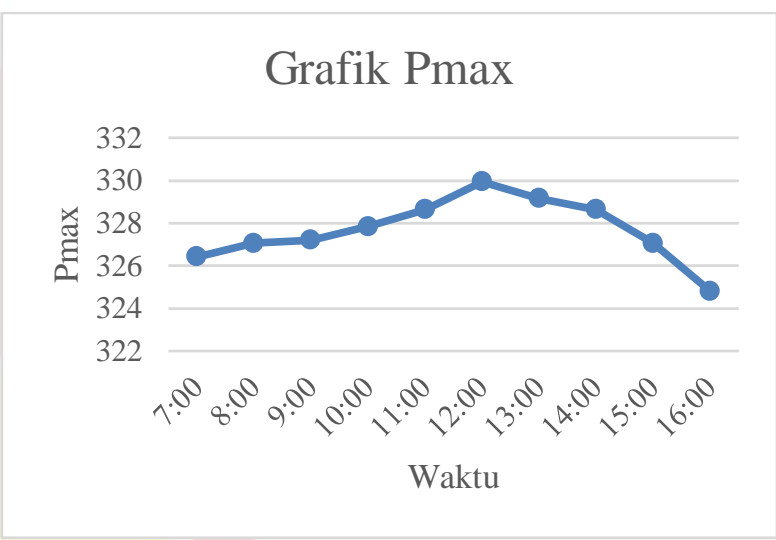

Gambar 13. Grafik Pmax

Setelah memasukkan data didalam tabel dan menghitung rata rata daya langkah selanjutnya adalah menghitung presentase rata-rata daya terhadap spektek pada solar panel. Perhitungan presentase rata rata sebagai berikut :

$$
\begin{aligned}
\frac{\text { Pmax rata rata pada avometer }}{\text { Pmax rata rata pada spektek }} \times 100 \% \\
=\frac{327,679}{330} \times 100 \%=99,29 \%
\end{aligned}
$$

Hasil 99,29\% merupakan presentase pembuktian antara Pmax rata rata pada Avometer. Dari dua hasil presentase pembuktian diatas bisa disimpulkan bahwa kinerja dari solar panel Kereta Lori PPI Madiun bekerja dengan optimal.

Kapasitas battery lithium pada Kereta Lori PPI Madiun yaitu 20 Ah. Angka Volt pada battery lithium saat tidak dapat di operasikan 59,3 Volt Maka harus dilaksanakan pengisian menggunakan solar panel, setelah di isi sampai penuh akan menunjukkan angka 67,3 Volt.

Dari gambar di atas bisa dihitung waktu yang diperlukan dengan rumus sebagai berikut :

$\frac{\text { Ah awal }}{\text { waktu awal }}=\frac{\text { Ah akhir }}{\text { waktuakhir }}$ 
$\frac{0,750 \mathrm{Ah}}{30 \text { menit }}=\frac{20 \mathrm{Ah}}{\text { waktuakhir }}$

Waktu akhir $=\frac{600}{0,750}=800$ Menit $(13$ jam 20 menit)

Waktu yang diperlukan untuk mengisi battery Lithium menggunakan Solar panel adalah 800 menit atau 13 jam 20 menit pada penyinaran pukul 10:00 WIB. Dengan kondisi battery tersebut lori inspeksi elektrik Politeknik Perkeretaapian Indonesia Madiun mampu menempuh sejauh $11 \mathrm{~km}$ dengan beban 4 orang dewasa.

\section{Perencanaan Alat Pengukur Geometri Jalan Rel}

Alat Pengukur Geometri Jalan Rel Pada Lori Inspeksi adalah alat yang dirancang sebagai modifikasi dari alat yang telah ada sebelumnya dengan meningkatkan efisiensi penggunaan tapi tetap mempertahankan keandalan dan keakuratan dalam pengukuran. Alat ini direncanakan memiliki fungsi yang sama dari 2 alat sebelumnya, yaitu meter gauge dan rail profile gauge. Alat ini diharapkan mampu mengambil data pengukuran inspeksi meliputi lebar jalan rel dan beda tinggi kedua rel seperti fungsi meter gauge dan keausan rel seperti fungsi rail profile gauge secara elektrik dan terpasang pada lori inspeksi. Alat ini bekerja jika alat diturunkan dan terpasang di jalur rel dan dapat diangkat kembali jika tidak dilakukan kegiatan inspeksi. Alat ini terdiri dari rangkaian catu daya, sensor gyroscope, sensor jarak ultrasonik, displacement sensor, dan motor DC yang semuanya terhubung dengan Arduino Uno pada tubuh alat untuk diambil data dan dikirim ke lcd untuk ditampilkan hasil pengukuran yang terdapat pada dashboard lori inspeksi elektrik PPI Madiun.

Desain direncanakan sesuai spesifikasi teknis jalan rel di lapangan. Sesuai dengan lebar spoor 1067 mm, ketinggian lori, maka perhitungan dimensi dan desain disesuaikan dengan pengamatan kondisi di lapangan.

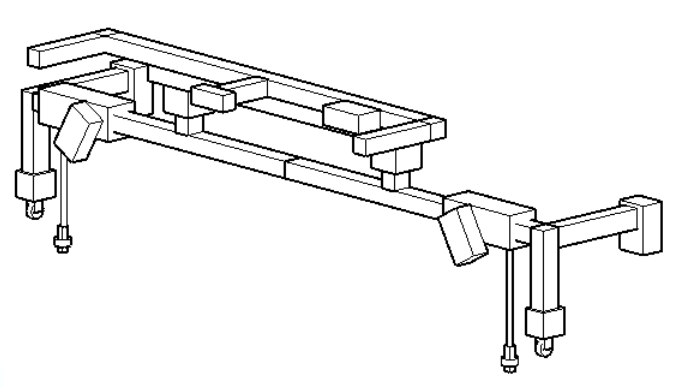

Gambar 14. Desain alat ukur geometri rel

Tabel 5. Spesifikasi Alat

\begin{tabular}{|c|c|c|}
\hline \multicolumn{2}{|l|}{ Spesifikasi } & \multirow[t]{2}{*}{ Keterangan } \\
\hline Koneksi & Kabel & \\
\hline \multirow[t]{2}{*}{ Tampilan } & \multicolumn{2}{|l|}{ LCD Monitor } \\
\hline & Ukuran & $2 \times 16$ \\
\hline \multirow[t]{2}{*}{ Rangka } & Bahan & Stainless Steel \\
\hline & Dimensi & $1080 \times 20 \times 30$ \\
\hline $\begin{array}{l}\text { Sumber } \\
\text { Tenaga }\end{array}$ & $\mathrm{AC} 60 \mathrm{~V}$ & Convert to DC $12 \mathrm{~V}$ \\
\hline Platform & Mikrokontroler & Arduino Uno \\
\hline Motor & Motor DC & Penggerak Mekanik \\
\hline Pengukuran & \multicolumn{2}{|l|}{ Lebar Spoor } \\
\hline & Jenis Track & $1067 \mathrm{~mm}$ \\
\hline & Jenis Sensor & Non-kontak MB1013 \\
\hline & Akurasi & $1 \mathrm{~mm}$ \\
\hline & \multicolumn{2}{|l|}{ Keausan Rel } \\
\hline & Jenis Track & $1067 \mathrm{~mm}$ \\
\hline & Jenis Sensor & \multirow{2}{*}{$\begin{array}{l}\text { Kontak Linear } \\
\text { Displacement Sensor }\end{array}$} \\
\hline & & \\
\hline & Akurasi & $0,1 \mathrm{~mm}$ \\
\hline & \multicolumn{2}{|l|}{ Elevasi } \\
\hline & Jenis Sensor & Gyroscope MPU6050 \\
\hline
\end{tabular}

\section{KESIMPULAN}

Berdasarkan penelitian pembuatan lori inspeksi elektrik Politeknik Perkeretaapian Indonesia Madiun dengan kesimpulan sebagai berikut :

1. Motor penggerak menggunakan motor listrik BLDC (Brushless direct current) dengan daya 2680 Watt, arus 35 A dan kecepatan putar $4250 \mathrm{Rpm}$ yang ramah lingkungan.

2. Roda lori inspeksi menggunakan struktur monoblok dengan proses pengecoran material besi cor nodular (FCD), memiliki tingkat kekerasan rata-rata $191 \mathrm{HB}$.

3. Rubber damper terbuat dari bahan: Karet alam 55\%, Carbon black 25\%, White oil 5\%, Zine oxide 3\%, Accelerator 2\%, Anti Oxidant 2\%, Steread Axid 3\%, dan Sulfur 5\%. 
4. Bodi lori inspeksi terbuat dari material komposit jenis fibre reinforced polymers of plastics (FRP) yang memiliki nilai tegangan Tarik sebesar $55 \mathrm{MPa}$ dan nilai regangan sebesar $1 \%$.

5. Solar panel dapat bekerja dengan optimal dengan presentasi Pmax hampir 99,29\% dan kemampuan jarak tempuh sejauh $11 \mathrm{Km}$.

6. Alat pengukur geometri jalan rel dilengkapi dengan sensor maxbotik sebagai pendeteksi lebar jalan rel, gyroscope sebagai pendeteksi beda tinggi dan KTR displacement sensor sebagai pendeteksi keausan rel.

\section{DAFTAR PUSTAKA}

Arifin, Jaenal. 2017. Pengaruh JenissElektroda TerhadapsSifat Mekanik HasilsPengelasan Smaw BajasAstm A36. Jurusan Teknik Mesin, Fakultas Teknik, Universitas Wahid Hasyim Semarang: Semarang.

Demollic. (2010).Pembuatan Bodi Mobil dan Modifikasi Chasis. Tugas Akhir Jurusan Teknik Mesin Otomotif. Surakarta : Universitas Sebelas Maret.

Dimas T. (2016). Pembuatan Produk dan Moulding Bumper Belakang Mobil Kijang Innova (V-2005) Berbahan Serat Glass Acak. Tugas Akhir Jurusan Teknik Mesin. Yogyakarta: Politeknik Muhammadiyah Yogyakarta.

Hestanto. 2007. Teoris Dasar Pemesinan Bubut.

https://www.hestanto.web.id/teoridasar-mesin-bubut/. Diakses pada tanggal 9 Desember 2019.

Masyrukan. 2015. "Penelitian Sifat Fisis Dan Mekanis Baja Karbon Rendah
Akibat Pengaruh Proses Pengarbonan Dari Arang Kayu Jati”. Jurusan Teknik Mesin Universitas Muhammadiyah, Surakarta.

Najah, M. A. 2018. Rancang Bangun Alat Inspeksi Jalan Rel Pada Lori Inspeksi dengan Menggunakan Sensor Maxbotix MB1013 dan Controller Raspberry PI. Madiun.

Nugroho, Yosep Dwi. (2016). Karakteristik Komposit Serat Glass Dengan Variasi Jumlah Lapisan Serat. Skripsi Jurusan Teknik Mesin. Yogyakarta: Universitas Sanata Dharma.

Pemerintah RepubliksIndonesia. 2007. Undang-Undang Republik Indonesias No.23 Tahun 2007 tentang Perkeretaapian. Jakarta: Kementerian Perhubungan.

Priambodo, Bambang. 1981. Teknologi Mekanik Jilid 2. Jakarta: Airlangga.

Rahayu S., Setyowati P, Supriyanto., 2004. Karakteristik Karet Ebonit yang Dibuat dengan Berbagai Variasi Rasio RSSI/Riklim dan Jumlah Belerang, Majalah Kulit, Karet, dan Plastik Vol.20 No. 1 (Juli 2004) : 10-14.

Supriyanto, Deris. 2007. "Penyambungan Plat Besi Dengan Menggunakan Proses Pengelasan Listrik”. Teknik Mesin, Universitas Indonesia, Depok.

Yuspian, Nanang, Bayu. 2017. "Analisa Pengaruh Pengelasan Listrik Terhadap Sifat Mekanik Baja Karbon Rendah Dan Baja Karbon Tinggi”. Teknik Mesin Fakultas Teknik Universitas Halu Oleo, Kendari. 